For: Dutt, Amitava and Benjamin Radcliff (eds.). Happiness, Economics and Politics. Cheltenham, U.K. and Northampton, MA: Edward Elgar.

\title{
Should NATIONAL HAPPINESS BE MAXIMIZED?
}

\author{
Bruno S. Frey* \\ University of Zurich
}

\author{
Alois Stutzer \\ University of Basel
}

June 23, 2008

\begin{abstract}
Cross-disciplinary 'happiness research' has made big progress in the measurement of individual welfare. This development makes it tempting to pursue the old dream of maximizing aggregate happiness as a social welfare function. However, we postulate that the appropriate approach is not to maximize aggregate happiness in seeking to improve outcomes by direct policy interventions. The goal of happiness research should rather be to improve the nature of the processes through which individuals can express their preferences. Individuals should become better able to advance their idea of the good life, both individually and collectively.
\end{abstract}

JEL Classifications: D60, D70, H11, I31

Keywords: Economic policy, happiness, life satisfaction, political economy, social welfare, utility

\footnotetext{
* Bruno S. Frey: Institute for Empirical Research in Economics, University of Zurich, Winterthurerstrasse 30, CH-8006 Zurich, Switzerland. Phone: +41 (0)44 63437 30, fax: +41 (0)44 63435 99, email: bsfrey@iew.uzh.ch.

Alois Stutzer: Department of Business and Economics, University of Basel, Petersgraben 51, CH-4003 Basel, Switzerland. Phone: +41 (0)61 26733 61, fax: +41 (0)61 26733 40, email: alois.stutzer@unibas.ch.

Both authors are also affiliated with CREMA - Center for Research in Economics, Management and the Arts.

We are grateful to Bernd Hayo and the participants of the European Public Choice Conference and the Conference on New Directions in the Study of Happiness at the University of Notre Dame for helpful comments.
} 


\section{Introduction}

Cross-disciplinary 'happiness research' has attracted great attention within the social sciences as well as in the public. This is reflected in a massive increase of scholarly work on people's subjective well-being and frequent featuring of happiness research in blogs, in the media, as well as in publications of think tanks. ${ }^{1}$

A case in point is the empirical study of happiness in economics. Within ten years, many insights about the determinants of individual well-being were attained (for surveys see Frey and Stutzer 2002a,b; van Praag and Ferrer-i-Carbonell 2004; Layard 2005; Di Tella and MacCulloch 2006; Frey 2008). Moreover, the separation of traditional decision utility from experienced utility as reflected in subjective well-being challenges the orthodoxy of the revealed preference approach in economics (Kahneman et al. 1997; Stutzer and Frey 2007). Individuals' ex post evaluation of their experiences now allows us to directly study problems of self-control and utility misprediction (Frey and Stutzer 2008; Kahneman and Thaler 2006); Stutzer this volume).

We plead guilty for being euphoric about the advances in happiness research. In addition to seeking to explain the determinants and consequences of happiness, a big effort has been made to derive implications for policy. We argue that it is tempting to apply happiness research in a technocratic way. This is best visible in the idea of maximizing aggregate happiness as a social welfare function. This is, however, a mistaken direction to go. It neglects the insights from political economics and fails to reflect the rich insights from happiness research.

The next section discusses the advances in measurement enabling empirical happiness research. Section III sketches how the idea of maximizing social welfare has been taken up in happiness research. The following two sections discuss two major sets of objections against this approach, the first based on classical welfare economics, the second based on happiness research itself. Section VI deals with the fundamental objections from political economy to happiness maximization. The problem of incentive distortions induced by the happiness maximization approach is discussed in section VII. An alternative approach to use the insights of happiness research for policy is developed in section VIII, and section IX concludes.

\footnotetext{
${ }^{1}$ See, e.g., the publications by the CATO Institute (Wilkinson 2007), the Institute of Economic Affairs (Johns and Ormerod 2007) or the New Economics Foundation (Shah and Marks 2004).
} 


\section{Happiness Can Be Usefully Measured}

Many social scientists, and in particular economists, have traditionally been most skeptical about direct measures of individual well-being or utility. They are taken to be private experiences felt in many different ways that can neither be summed up, expressed on a scale, nor be compared between individuals. Economic analysis therefore derives utility indirectly by looking at revealed behavior rather than at direct statements by the individuals of their state of utility.

The situation has recently changed dramatically. Great advances have been made in measuring happiness (see also Veenhoven this volume). There is now a wide-spread consensus among scholars dealing with these issues that experienced utility and individual welfare can be measured with some accuracy (e.g. (Kahneman et al. 1999; Diener 2005; Kahneman and Krueger 2006). One indicator that such measurements credibly capture important aspects of well-being is shown by the fact that they correlate with behavior and aspects generally associated with happiness. Reliability studies have found that reported subjective well-being is moderately stable and sensitive to changing life circumstances (e.g. Ehrhardt et al. 2000; Schimmack and Oishi 2005). Consistency tests reveal that happy people are more often smiling during social interactions (Fernández-Dols and Ruiz-Belda 1995), are rated as happy by friends and family members (e.g. Sandvik et al. 1993; Lepper 1998), as well as by spouses (Costa and McCrae 1988), express more frequent expressions of positive emotions, are more optimistic, are more sociable and extravert, and enjoy better sleep (Frey and Stutzer 2002b: 33). Happy persons are also less likely to commit suicide (Koivumaa Honkanen et al. 2001; Helliwell 2007).

There is no single, overriding concept that motivates all individual behavior and registers all experiences, feelings and judgments; the following conceptions of individual well-being can be distinguished (Diener 2005):

- Subjective well-being referring to different types of positive and negative evaluations made by people regarding their lives;

- Positive and negative affect denoting pleasant and unpleasant moods and emotions, respectively, such as joy and sadness;

- Happiness has been used in many different meanings. It often refers to the balance between short term positive and negative emotions; 
- Life satisfaction refers to how an individual evaluates his or her life taken as a whole and is a broad, reflective appraisal the person makes of his or her life;

- Quality of life designates the degree to which a person's life is desirable rather than undesirable, and is often connected to external components such as the natural environment. It is often expressed as "objective" in contrast to subjective well-being.

In our analysis, we do not in general distinguish between these concepts but simply use the term "happiness". Distinctions between the various concepts are only made when it comes to particular measurements and when it is alluded to empirical studies.

There are five prominent measures of individual well-being:

\section{Asking People: Global Evaluations of Individual Life Satisfaction}

This approach seeks to capture happiness by asking a representative sample of individuals about their overall satisfaction with the life they lead. A prominent example of a single-item question on a three-point scale is in the General Social Surveys (Davis et al. 2001). It asks the question: "Taken all together, how would you say things are these days - would you say that you are very happy, pretty happy, or not too happy?" Life satisfaction is assessed on a scale from one (dissatisfied) to ten (satisfied) in the World Values Survey (Inglehart et al. 2000). People answer the question: "All things considered, how satisfied are you with your life as a whole these days?" The Eurobarometer Surveys, covering all members of the European Union, asks a similar question: "On the whole, are you very satisfied, fairly satisfied, not very satisfied, or not at all satisfied with the life you lead?" Among the multiple-item approaches, the most prominent is the Satisfaction With Life Scale (Diener et al. 1985), composed of five questions, rated on a scale from one to seven (see the survey about various measures of subjective well-being by (Andrews and Robinson 1991).

Despite the favorable evaluation of direct measures of individual well-being, as subjective survey data are based on individuals' judgments, they are prone to many biases. Reported subjective well-being is, e.g., expected to depend on the order of questions, the wording of question, scales applied, actual mood and the selection of information processed (Schwarz and Strack 1999). The relevance of these errors, however, depends on the intended usage of the data. Often, the main use of happiness measures is not to compare levels in an absolute sense between single individuals. Research rather seeks to identify the determinants of happiness. For that purpose, it is often neither necessary to assume that reported subjective well-being is cardinally measurable nor that it is interpersonally comparable. 
Almost all of the empirical work so far undertaken in happiness research in economics has been based on representative, large-scale sampling of individuals' global evaluations of their life satisfaction. The great advantage of this measurement approach is its good performance compared to its cost, as well as its availability for a large number of countries and periods. Thus, for example, the surveys on life satisfaction contained in the World Values Survey today cover 80 countries representing over 80 percent of the world's population over 4 periods.

\section{Experience Sampling Method}

This approach collects information on individuals' experiences in real time in their natural environments (Csikszentmihalyi and Hunter 2003; Scollon et al. 2003). A representative selection of individuals are supplied with a beeper or a hand held computer asking them at random instances of time to immediately answer a battery of questions with regard to momentary positive and negative affects in that particular moment. Respondents are also asked to state the intensity of their feelings. This electronic diary seeks to practically apply Edgeworth's (1881) old idea of capturing utility by a "hedonimeter" capturing immediate experience. Happiness can then be calculated by the aggregation of these instantaneous statements of affect.

This method has so far not been applied on any large scale. It is more costly than representative surveys of global evaluations of life satisfaction.

\section{Day Reconstruction Method}

The Day Reconstruction Method of measuring happiness is a special variant of experience sampling (Kahneman et al. 2004a). Respondents are asked to reconstruct the previous day by filling out a structured questionnaire. The respondents first recall the activities undertaken the previous day into working memory by producing a sequence of episodes. They then describe each episode in detail by identifying when, what, where, and with whom the episode took place. The respondents then rate these episodes in terms of positive affect (happy, warm/friendly, enjoying myself) or negative affect (frustrated/annoyed, depressed/blue, hassled/pushed around, angry/hostile, worried/anxious, criticized/put down). Moreover, the feeling of being competent, impatient for the episode to end or tired is also asked.

The Day Reconstruction Method allows more refined measures of happiness than is the case with representative surveys confined to one question. By carefully splitting up the past day into episodes, the respondents are induced to think carefully about how they felt during each 
time period. They are less prone to distortions of memory known to be especially severe in the recall of affect (Robinson and Clore 2002). However, the weighing of episodes that matter for people's overall evaluation of their life is determined by the researcher according to some aggregation rules and not by the subjects themselves.

The Day Reconstruction Method is new and has so far been empirically used only on an experimental basis. It must be left to the future to what extent, and for which specific issues, happiness researchers will rely on this measurement approach. It is moreover open to what extent individuals are able and willing to correctly remember the emotions in past episodes (though they are quite recent).

\section{The U-Index}

In the measures so far discussed there is no guarantee that the scales used map the corresponding feelings into numbers representing cardinal values that can be compared across people. The question is whether the answer of "very satisfied" is really worth twice the value of the answer "not satisfied". Kahneman and Krueger (2006) propose the U-Index (for "unpleasant") based on the Day Reconstruction Method to avoid this cardinality concern. The U-Index is defined as the fraction of time per day that an individual spends in an unpleasant state. An episode is unpleasant if the most intense feeling the individual experiences in that episode is a negative one. The U-Index relies on the observation that the dominant emotional state of most of the people during most of the time is positive. Hence any episode when a negative feeling occurs is a significant occurrence. It is thus assumed that a dominant negative emotion colors an entire episode. Obviously, this is a special assumption focusing on a particular, unpleasant, state of mind while positive experiences are disregarded.

\section{Brain Imaging}

A quite different measuring approach to approximate utility in a quantitative way consists in scanning individuals' brain activities. It is relied on functional magnetic resonance imaging (fMRI) which tracks blood flow in the brain using changes in magnetic properties due to blood oxygenation (on neuroeconomics, see Zak 2004; Camerer et al. 2005; Fehr et al. 2005). Happy persons reveal a characteristic pattern of electrocortical activity. They exhibit greater activity in the left than in the right prefrontal cortex (Davidson 2003; Pugno 2004). This prefrontal cortical asymmetry between more or less happy people further correlates behavioral activation (rather than inhibition), and even with antibody response to influenza vaccine (Urry et al. 2004). It is important to note, however, that the quality of physiological measures 
depends on the quality of self-reported measures of well-being with which they were originally calibrated.

For many tasks self-reported measures of life satisfaction have proved to perform in a satisfactory way especially for the issues economists are mostly interested in. It is so far the best empirical approximation available to the concept of individual welfare used in economic theory.

The measurement of happiness has proved to yield useful insights to better understand the economy and society. On the macro-level, it is increasingly accepted as a complement to the long-established measures of national income, thus following the lead of the social indicators approach and of the capabilities approach. ${ }^{2}$ The United Kingdom and Australia as well as some other countries are committed to producing national measures of well-being, and already back in the 1970s the Kingdom of Bhutan proclaimed that it wants to maximize Gross National Happiness rather than Gross National Income (Ura and Galay 2004). On the scientific side, a group of fifty well-known scholars promotes the idea of "National Indicators of Subjective Well-Being and Ill-Being" (Diener 2005). We also signed the guidelines because we find it important that measures of subjective well-being are further introduced and improved to get a better understanding of individual welfare.

At the micro-level, the measurement of happiness allows us a more direct welfare analysis than in standard welfare economics, and therefore is a useful complement. The exclusive reliance on revealed preference in micro-economic theory ${ }^{3}$ is valid only if individuals act in a fully rational way. But in reality people often make inconsistent choices: they fail to learn from experience or do so incorrectly, refuse to engage in beneficial trades, compare themselves to others, have insufficient self-control, mispredict future utilities of consumption, and depart in many other ways from the model of the rational economic agent (e.g. Rabin 1998). To the extent that these effects occur, individual choices do not reflect true or normative preferences (Beshears et al. 2008), and expanding people's opportunities will not necessarily increase their utility (for an application to TV viewing, see Benesch et al. 2006). This may lead to fundamental changes in evaluations, an example being Kahneman and

\footnotetext{
${ }^{2}$ Recent surveys on social indicators are provided in Michalos (2005), Hass et al. (2003), and BergerSchmitt and Jankowitsch (1999). For the capabilities approach based on the work by Sen $(1992 ; 1999)$ and Nussbaum (1999; 2000) see Comim (2005) and Gasper (2005).

${ }^{3}$ But not in (applied) benefit cost analysis where the method of stated preference, especially via contingent valuation, is central.
} 
Thaler's (2006: 11) statement that "It is certainly possible that American workers would be happier with more vacation and less pay".

\section{III.Maximizing Aggregate Happiness}

To focus on aggregate happiness rather than Gross National Product (or another measure of economic activity) as an indicator of social welfare has several important advantages. As the limits of the traditional indicators are well documented (see, e.g., Frey and Stutzer 2002a, chapter 2), it suffices to briefly list them and put them in comparison with measures of happiness.

1. Measures of happiness include non-material aspects of human well-being such as the influence of social relations, autonomy, and self-determination. These are excluded, or most insufficiently included, in the traditional national accounts and therewith in GNP. One of the major challenges of happiness research is indeed to explain the "Easterlin Paradox" (Easterlin 1974; 1995; 2001) showing that in many countries real per capita income has dramatically increased but happiness has more or less stayed constant (see recently, e.g., Di Tella and MacCulloch 2005). They go well beyond existing extensions of GNP such as the „Measure of Economic Welfare“ (Nordhaus and Tobin 1972), „Economic Aspects of Welfare“ (Zolatas 1981), „Index of Sustainable Economic Welfare“ (Daly and Cobb 1989) or "Human Development Index" (United Nations Development Programme 2005). These indicators exhibit a strongly different development over time than happiness indicators (see, e.g., Blanchflower and Oswald $2005)^{4}$

2. Measures of happiness consider outcome aspects of components already included in GNP via input measures. This holds in particular with respect to the vast area of government activity (measured in GNP by the costs of material and of labor). It is also directly relevant for (public) health and educational expenditures. „Social Indicators“ (e.g. the "Index of Social Progress" by Estes 1988) mostly measure the input side such as the number of hospital beds and of doctors, or of class-rooms and teachers.

3. Measures of happiness look at subjectively evaluated outcomes in line with the basic methodological approach of economics. In contrast, the capabilities approach and the

\footnotetext{
${ }^{4}$ But their result is criticized by Leigh and Wolfers (2006).
} 
„Human Development Index“ by the United Nations look at objectively observable functionings (Sen 1985; 1992; Nussbaum 1999; Sen 1999; Nussbaum 2000).

The question arises whether for these reasons the maximization of (measured) happiness as a proxy for social welfare is a worthwhile approach to pursue. To maximize social welfare as the ultimate goal of economic policy is an old dream in economics dating back to Bentham (1789) and later Edgeworth (1881), and introduced into contemporary economics by Tinbergen (1956) and Theil (1964). This dream is closely associated with the effort of turning economics into a natural science comparable to physics. Consistent with this view, Edgeworth called his book "Mathematical Psychics" (1881). A major problem of this approach was that the social welfare function to be maximized could not be empirically measured. Di Tella, MacCulloch and Oswald (2001) refer to this issue in the opening statement to their paper:

„Modern macroeconomics textbooks rest upon the assumption of a social welfare function defined on inflation, $\pi$, and unemployment, $U$. However, no formal evidence for the existence of such a function has been presented in the literature. Although an optimal policy rule cannot be chosen unless the parameters of the presumed $\mathrm{W}(\pi, \mathrm{U})$ function are known, that has not prevented its use in a large theoretical literature in macroeconomics“" (p. 335).

The advent of happiness research has dramatically changed this situation: Aggregates of existing measures of subjective well-being can be used as an approximations to a social welfare function. The proposal of National Well-Being Accounts by Kahneman, Krueger, Schkade, Schwarz and Stone (2004b) seems indeed to reflect this spirit when they write:

"The goal of public policy is not to maximize measured GDP, so a better measure of well-being could help to inform policy. Here we propose measuring national well-being by weighting the time allocated to various activities by the subjective experiences associated with those activities" (p. 433).

The vision of aggregate happiness as a guideline for policy is also expressed by Layard in his well-received book on "Happiness" (2005):

“[...], there are many major choices where rules provide little guidance. There are pubic choices like how to treat criminals, or how to solve traffic problems. Simple appeals to principles of freedom or loving-kindness will help little here. [...] The answer can only be found from overarching objectives of maximising human happiness “ (p. 124).

The development made possible by happiness measures has several attractive properties. First, it enables to derive optimal policies in a numerical way, increasing the usefulness of evaluation exercises for government policy. Second, in contrast to postulating a social welfare function at the aggregate level based on a wide range of different outcome variables, the well- 
being figures provided by happiness research offer an overall evaluation based on individuals' judgments. Third, a measure of social welfare based on happiness data is democratic in the sense of attributing equal weight to every person. In contrast, the prices relevant for assessing the value of goods entering GNP are strongly determined by the preferences of people with high purchasing power. The preferences of individuals without income to spend are disregarded.

Despite these developments working to the advantage of the idea of social welfare maximization, we argue in the following sections that this approach should be rejected for a number of important reasons. Thereby, we do not simply retreat to the traditional welfaretheoretic objections against aggregate welfare maximization that we present in the next section.

\section{Welfare Economic Objections against Social Welfare Maximization}

Classical welfare economics, initially due to, and strongly influenced by, Robbins (1932) and Hicks and Allen (1934), has for a long time raised fundamental arguments against using the concept of aggregate social welfare in contrast to individual welfare. The two most important, and partially interconnected (see Sen 1970), objections to the concept of aggregate social welfare are, first, the impossibility of cardinal measurement and interpersonal comparisons, and, second, the impossibility theorem.

Since Arrow (1951) it has been widely accepted that under a number of „reasonable“ conditions, no social welfare function exists that generally ranks individual orderings of outcomes consistently, except a dictatorship. This impossibility result spawned a huge amount of literature (called "Social Choice"), analyzing its robustness to modifications of the assumptions. Theorem after theorem demonstrated that almost all changes in the axiomatic structure left the dictatorial result unchanged (see, e.g., Sen 1970; Sen 1995; Slesnick 1998). It has been concluded that ,there is no way we can use empirical observations on their own to produce an ethically satisfactory cardinalization, let alone an ethically satisfactory social welfare ordering“ (Hammond 1991: 220-21). Does this verdict apply to happiness functions in their capacity as social welfare functions? The answer depends on whether one thinks that the premises of classical welfare economics still hold.

The ordinalist revolution in economics on which classical micro-economics is firmly based takes it for granted that individual welfare can only be measured in an ordinal, but not in a cardinal way, and that it makes no sense to make interpersonal comparisons of utility. These 
are exactly the fundamental assumptions where the counter revolution of happiness research sets in. If the accumulated evidence (partly mentioned above) is judged sufficient in the sense that it allows to cardinally measure and interpersonally compare happiness then a, or in fact many, social welfare functions exist. An appealing social welfare function probably is the unweighted sum of individual cardinal welfares or happiness. However, given that people have preferences over the distribution of happiness scores in a society, no consistent social welfare ordering can be derived.

We do not take a position here. We think, however, that both cardinality and interpersonal comparability may be less of a problem on a practical level than on a theoretical level. ${ }^{5}$ Moreover, for many applications milder assumptions are sufficient. An important example is the valuation of public goods and public bads based on the life satisfaction approach (see, e.g., Frey et al. 2004). Scores of life satisfaction are reported on an ordinal scale. Using adequate statistical techniques like ordered probit or ordered logit, the ordinal information is, however, sufficient to calculate a compensating surplus. Moreover, interpersonal comparability at the level of the single individual is not a necessary condition for valuing public goods in the life satisfaction approach. It is sufficient if individual specific response frames do not systematically vary between different groups exposed to different levels of the public good either across space or over time.

It may be concluded that while the objections by classical welfare economics must be taken seriously, the existing state of research suggests that, for many purposes, happiness or reported subjective well-being is a satisfactory empirical approximation to individual welfare. However, the limits remain of setting up a consistent measure of aggregate social welfare.

\section{Objections from Happiness Research against Social Welfare Maximization}

In happiness research two phenomena are studied that put the maximization of aggregate happiness into question as an objective of public policy.

The first phenomenon that gives rise to reservations has to do with one of the most central findings of happiness research: many changes of life circumstances have only a short-lived effect on reported subjective well-being because people adapt (Frederick and Loewenstein 1999). Extreme and well-known examples are paraplegics who after a time of hardship in the

\footnotetext{
${ }^{5}$ Interestingly enough psychologists (who otherwise are very demanding with respect to measurement) seem to be more comfortable with respect to comparing indicators of feelings or utility across individuals (Kahneman et al. 2004b: 432).
} 
long run report themselves to be only a little less happy than before, and lottery winners who after a short period of elation report themselves not to be much happier than before (Brickman et al. 1978). A more recent study based on longitudinal data finds that average life satisfaction drops when being subjected to a moderate disability but almost fully recovers to the predisability level after two years. In the case of a severe disability the recovery, however, is incomplete (Oswald and Powdthavee 2008). More on the bright side, the period leading up to marriage significantly raises average happiness but over the course of marriage the happiness level turns back to only little above the pre-marriage level (Stutzer and Frey 2006).

The second, closely related phenomenon is the change of people's aspirations due to changes in their life circumstances. In the context of economics, the most important finding is that people quite rapidly adjust to increases in their income: after about one year two-thirds or more of the benefits of an increase in income wear off as people increase their income aspirations (Stutzer 2004; van Praag and Ferrer-i-Carbonell 2004). This process has become known as the aspiration treadmill and has been used to explain the Easterlin Paradox mentioned above.

Hedonic adaptation and the aspiration treadmill are not problematic as such for the measurement of individual welfare. However, they have great consequences for social welfare maximization depending on how they are treated. Imagine courts have to decide about compensation for losses suffered in a car accident. For the same physical harm, shall they award lower damages to people with a strong capacity to adapt and higher damages to others? Or in the area of government taxation, what costs of taxation shall be taken into account? Materialists with high income aspirations suffer a great deal from personal income taxes. Shall they be exempted from tax and government services be financed by people who can easily arrange with what ever material living standard they experience?

What matters in our context is that the way to deal with hedonic adaptation and the aspiration treadmill are not part of social welfare maximization but must be decided on a more fundamental level. Thus one needs a social decision making mechanism to indicate how adaptation and aspiration effects have to be dealt with in public policy. Obviously such decisions have grave consequences for economic policy to which the social welfare maximization approach does not contribute anything. 


\section{Objections from Political Economics to the Maximization of Aggregate Happiness}

The social welfare maximization approach disregards, and tries to substitute for, existing political institutions and processes. This is the "benevolent dictator" view castigated in Constitutional Political Economy and which needs not be repeated here. ${ }^{6}$ The essential message is that in a democracy there are constitutionally designed rules and institutions allowing citizens to reveal their preferences, and to provide politicians (the government) with an incentive to put them into reality. The maximization of a social welfare function as such is an intellectual exercise. Even if the government were to take notice it has no incentive to follow it.

These relationships can be formulated more precisely. The social welfare or happiness function $\mathrm{H}$ is

$$
\mathrm{H}=\mathrm{H}(\mathrm{X}, \mathrm{Z}) \text {, }
$$

$\mathrm{X}$ and $\mathrm{Z}$ are the determinants of happiness as determined in empirically estimated happiness functions. $\mathrm{X}$ are those factors which can be influenced by the government, and $\mathrm{Z}$ are exogenous determinants, among them demographic factors as age, or genetic influences.

A government does not maximize this aggregate social welfare or happiness function $\mathrm{H}$. Rather, in a democracy politicians have to take into account the preferences of its citizens as revealed in vote outcomes. ${ }^{7}$ The vote function reflects the influence of the happiness of the voters $\mathrm{H}$, the factors the government can influence $\mathrm{X}$ and exogenous factors $\mathrm{Y}$ beyond the government's influence:

$$
\mathrm{V}=\mathrm{V}(\mathrm{H}, \mathrm{X}, \mathrm{Y})
$$

The government politicians seek to maximize an objective function $\mathrm{G}$ by optimally choosing $\mathrm{X}$. In so far as they are benevolent, it is composed of what they believe to make the population (or at least the voters) happy $\mathrm{H}$, the private benefits of politicians in power $\mathrm{P}$ (gained by rent seeking), and the ideological goals I of the politicians' party or coalition in power:

$$
\mathrm{G}=\mathrm{G}(\mathrm{H}, \mathrm{P}, \mathrm{I})
$$

\footnotetext{
${ }^{6}$ Originally Buchanan and Tullock (1962), see also Frey (1983), Brennan and Buchanan (1986), Mueller (1996; 2003), Vanberg (2005).

${ }^{7}$ In authoritarian and dictatorial systems the rulers also have to some extent to take into account the population's wishes in order not to risk rebellions and revolutions, and thus to be thrown out of power.
} 
This objective function is maximized subject to the normal resource constraints and subject to the re-election constraint

$$
\mathrm{V} \geq \mathrm{V}^{\prime}
$$

where $V^{\prime}$ is determined by the political system (it differs e.g. between a majoritarian and a proportional voting system).

Two states can be distinguished:

(i) When the re-election constraint is non-binding, the government maximizes its own goal function $\mathrm{G}$;

(ii) When the re-election constraint is binding, the government maximizes votes $\mathrm{V}$.

Against the (implicit) presumption of the social welfare maximization approach the government does not generally maximize the happiness $\mathrm{H}$ in the population (or at least of voters); it does so only under very restrictive conditions. Government maximizes votes only when its re-election chance is low, and when the determinants of votes $\mathrm{V}$ are the same as those of happiness $\mathrm{H}$.

In general, the factors $\mathrm{X}$ under the control of government have a different impact on votes $\mathrm{V}$ than on happiness $\mathrm{H}$. In some instances, the voters do not make the government responsible for some impacts of $\mathrm{X}$ (i.e. $\mathrm{dV} / \mathrm{dX}=0$ ) though it influences happiness $\mathrm{H}$, and the reverse. When the government's re-election chance looks good, the government maximizes G whereby ideological factors enter government behavior; they do not necessarily raise happiness $\mathrm{H}$ but often cater for special groups in the population in order to reap private benefits $P$.

The social welfare maximizing approach based on empirically estimated happiness functions thus disregards the institutions on which democracy is based. Citizens are reduced to "metric stations". The interaction between citizens and politicians, the interest representation by organized groups and the concomitant information and learning processes are disregarded.

\section{Induced Incentive Distortions}

So far it has been assumed that the decision to maximize social welfare in terms of aggregate (measured) happiness does not have any influence on the measurement of subjective wellbeing. This assumption is most doubtful. Indeed, the political use of aggregate happiness will 
certainly induce strategic interactions between the government and the individuals. Two kinds of distortions are to be taken into account.

Once aggregate happiness has become politically relevant the government, public bureaucracy and interest groups have an incentive to manipulate it. This has proved to be true for GNP and other economic indicators declared to be goals of government activity. As the rate of unemployment has become a politically important indicator, governments have started to influence it in order to suggest a better picture of the state of the labor market than is true in reality. Thus, for instance, persons long unemployed are defined to no longer belong to the work force and therewith do no longer raise the official rate of unemployment. It is also well known that the measure of budget deficit has been strongly manipulated by some European countries when the rules for entering the European Monetary Union required budget deficits not to exceed three percent of GDP and the public debt not to exceed sixty percent of GDP. Many EU member countries (most notably Greece and Italy) resorted to accounting tricks or "creative accounting" $"$ in order to meet these requirements though in reality they clearly violated them (see, e.g., Forte 2001; von Hagen and Wolff 2004). Such distortions of indicators were so widespread that observers stated that "[...] the determining factor for achieving membership of the planned European Monetary Union (EMU) seems to rely on widespread use of public-sector creative accounting measures" (Dafflon and Rossi 1999: 5960). In the (rare) case in which a government is unable to manipulate a particular indicator to its benefit, it has an incentive to create new indicators. This is easily possible in the case of happiness. As has been pointed out in the second section, a variety of indicators may capture individual well-being. Governments and pressure groups will choose those most beneficial to their respective interests or will even create new ones suiting them well.

The second systematic distortion stems from the incentive of respondents to misrepresent their well-being. When individuals become aware that the happiness level they report influences the behavior of political actors, they have an incentive to misrepresent it. They try to "play the system".

The two systematic distortions discussed represent a basic phenomenon even applying in the natural sciences. The Heisenberg Uncertainty Principle states that the observation of a system

\footnotetext{
${ }^{8}$ Creative accounting is no violation of the law but it is clearly against the spirit of the law and the accounting standards. It uses the rules, the flexibility provided by them and the omissions within them to make financial statements which look different from what is intended by the rule (Jameson 1988).
} 
fundamentally disturbs it. In the social sciences, both the observation and the public reporting can change the behavior observed of the persons involved. This reaction is known in macroeconomics as Goodhart's Law and the Lucas Critique (see Chrystal and Mizen 2003). Goodhart's Law (1975) states that any observed statistical relationship - such as the happiness function - will tend to collapse once pressure is placed upon it for control purposes. The Lucas Critique (1976) refers more specifically to econometric modeling: different policy making behavior influences the expectations of private agents and this changes behavior in a rational-expectations model.

\section{An Alternative Vision of How to Use Happiness Research for Policy}

Our discussion has endeavored to show that the maximization of aggregate happiness as a social welfare function is a doubtful approach for several reasons:

- Governments are not composed of purely benevolent politicians wanting to make the population as happy as possible. Rather, the personal interests of politicians also matter;

- The essential elements of democratic governance are disregarded: democracy does not simply consist in recording the reported well-being of the citizens;

- The government has an incentive to manipulate the happiness indicators and to create new ones suiting their goals;

- The individuals have an incentive to misrepresent their happiness levels strategically in order to influence government policy in their favor.

Some might also argue that problems of cardinality and interpersonal comparability can never be fully overcome.

These arguments do, of course, not mean that the maximization of GNP would be preferable to maximizing aggregate happiness (however conceived). Rather, we argue that happiness research shall not aim at constructing a social welfare function at all but that the insights provided by happiness research should be used in a different way.

Our vision rests on the fundamental presumption that the quality of the political process is key to people's happiness and that the legitimacy of political action finally rests on the voluntary agreements of the citizens involved. Individuals' sovereignty should not be reduced to selfreports of one's well-being. It should also include the choice how to best pursue one's happiness privately and collectively. The claim is not for 'naïve' consumer or citizen sovereignty in the sense that behavior is always optimal. People are taken with their bounded 
rationality and bounded will power sometimes aware of their own limitations and sometimes only of those of their fellow citizens.

Accordingly, the political process should be institutionally structured so that people's common interests become the principal controlling force. Economic policy must help to establish those fundamental institutions, which make politicians and pubic bureaucrats most responsive to people's common interests and which finally lead to the best possible fulfillment of individual preferences. Thereby happiness (in its various forms) might not be people's ultimate goal. Other goals may, for instance, be loyalty, responsibility, self-esteem, freedom or personal development.

Research in constitutional economics helps us to identify which institutions serve the goal of preference fulfillment. Thereby happiness research provides insights about how and to what extent institutions have systematic effects on indicators of individual well-being. The focus is thus on institutions rather than specific policy interventions. To give an example, the focus ought rather be on the relationship between the fiscal constitution of a jurisdiction and people's subjective well-being than on the optimal tax scheme in terms of happiness. The range of institutions under study includes self-binding mechanisms, social norms, private and public law (i.e. the rules of the game) as well as constitutional conditions on how to choose rules.

The results gained from happiness research should be taken as inputs into the political process. These inputs have to prove themselves in political competition and in the discourse among citizens, and between citizens and politicians. This vision differs basically from an approach performing the maximization of a social welfare function.

The arguments raised should not be understood as a pleading against better measures of happiness. Measuring citizens' happiness should, however, not focus on generating an ever better single aggregate indicator but rather on improving proxies that allow insights about individual well-being broadly understood.

Happiness research has already produced many insights, which can be brought into the political discussion process. They include policy issues like, e.g., the role of direct democratic decision making in citizens' well-being (Frey and Stutzer 2000), the effect of mandatory retirement and mandatory schooling on happiness (Charles 2002; Oreopoulos 2005), the consequences of social work norms and birth control rights on women's well-being (Lalive and Stutzer 2007; Pezzini 2005), the impact of tobacco taxes on smokers' well-being (Gruber 
and Mullainathan 2005) or the relation between working time regulation and people's subjective well-being (Alesina et al. 2005). A competent overview of selected findings with policy relevance is provided in Diener and Seligman (2004).

\section{Concluding Remarks}

The objective of our paper was to outline two possible views about the role of happiness research in public policy. A discussion is warranted as the view matters for the choice of research questions and thus the kind of knowledge happiness research aims to provide, as well as for the people seen as addressees.

The big progress in the measurement of individual welfare makes it tempting to pursue the old dream of maximizing aggregate happiness as a social welfare function. Improvements in individual well-being are claimed to be measured directly and politics is seen as taking up advice and implementing it with suitable interventions in the political process.

However, we postulate that the appropriate approach is not to maximize aggregate happiness directly in seeking to improve outcomes by direct interventions. We rather see the role of happiness research in seeking to improve the nature of the processes. People should become better able to advance their idea of the good life, individually and collectively. They should be made aware that different issues require different measures and indicators of well-being. Happiness research should remain open to constructing a number of different indicators, reflecting well-being according to different aspects of life. Plurality is a necessary consequence of the procedural view outlined. This is in stark contrast to the maximization approach requiring one single objective.

All this does not mean that it would be useless to construct a National Happiness Indicator. It has an important role to fulfill as an important macroeconomic input in the political discourse. It helps us in overcoming the currently dominant orientation towards the Gross National Product centered on material concerns. Politicians get incentives to justify their actions in terms of a broader and better indicator of individual welfare. It is also useful in strengthening the yardstick competition between political units and political parties. "National" Happiness Indicators should therefore be disaggregated to regional, county, and communal levels. The useful role of having one happiness indicator (or, better still, several happiness indicators) is independent of maximizing the National Happiness Indicator. 


\section{References}

Alesina, Alberto, Edward Glaeser and Bruce Sacerdote (2005). Work and Leisure in the United States and Europe: Why So Different? In: Mark Gertler and Kenneth Rogoff (eds.). NBER Macroeconomics Annual 2005. Cambridge, MA: MIT Press: 1-64.

Andrews, Frank M. and John P. Robinson (1991). Measures of Subjective Well-Being. In: John P. Robinson, Phillip R. Shaver and Lawrence S. Wrightsman (eds.). Measures of Personality and Social Psychological Attitudes. San Diego, CA: Academic Press: 61114.

Arrow, Kenneth J. (1951). Social Choice and Individual Values. New York: John Wiley \& Sons.

Benesch, Christine, Bruno S. Frey and Alois Stutzer (2006). TV Channels, Self Control and Happiness. IEW Working Paper No. 301, University of Zurich.

Bentham, Jeremy (1789). An Introduction to the Principles of Morals and Legislation. Oxford: Clarendon Press.

Berger-Schmitt, Regina and Beate Jankowitsch (1999). Systems of Social Indicators and Social Reporting: State of the Art. EuReporting Working Paper No. 1, Mannheim: Zentrum für Umfragen, Methoden und Analysen (ZUMA).

Beshears, John, James J. Choi, David Laibson and Brigitte C. Madrian (2008). How Are Preferences Revealed? NBER Working Paper Series No. 13976, Cambridge, MA.

Blanchflower, David G. and Andrew J. Oswald (2005). Happiness and the Human Development Index: The Paradox of Australia. Australian Economic Review 38(3): 307318.

Brennan, Geoffrey and James M. Buchanan (1986). The Reason of Rules: Constitutional Political Economy. Cambridge, MA: Cambridge University Press.

Brickman, Philip, Dan Coates and Ronnie Janoff Bulman (1978). Lottery Winners and Accident Victims: Is Happiness Relative? Journal of Personality and Social Psychology 36(8): 917-927.

Buchanan, James M. and Gordon Tullock (1962). The Calculus of Consent. Logical Foundations of Constitutional Democracy. Ann Arbor: University of Michigan Press.

Camerer, Colin, George Loewenstein and Drazen Prelec (2005). Neuroeconomics: How Neuroscience Can Inform Economics. Journal of Economic Literature 43(1): 9-64.

Charles, Kerwin Kofi (2002). Is Retirement Depressing? Labor Force Inactivity and Psychological Well-Being in Later Life. NBER Working Paper No. 9033, Cambridge, MA.

Chrystal, K. Alec and Paul D. Mizen (2003). Goodhart's Law: Its Origins, Meaning and Implications for Monetary Policy. In: Paul D. Mizen (ed.). Central Banking, Monetary Theory and Practice: Essays in Honour of Charles Goodhart, vol. 1. Cheltenham, U.K. and Northampton, MA, USA: Edward Elgar: 221-243.

Comim, Flavio (2005). Capabilities and Happiness: Potential Synergies. Review of Social Economy 63(2): 161-171.

Costa, Paul T. and Robert R. McCrae (1988). Personality in Adulthood: A Six-Year Longitudinal Study of Self-Reports and Spouse Ratings on the Neo Personality Inventory. Journal of Personality and Social Psychology 54(5): 853-863.

Csikszentmihalyi, Mihaly and Jeremy Hunter (2003). Happiness in Everyday Life: The Uses of Experience Sampling. Journal of Happiness Studies 4(2): 185-199. 
Dafflon, Bernard and Sergio Rossi (1999). Public Accounting Fudges Towards Emu: A First Empirical Survey and Some Public Choice Considerations. Public Choice 101(1-2): 5984.

Daly, Herman E. and John B. Cobb (1989). For the Common Good: Redirecting the Economy toward Community, the Environment, and a Sustainable Future. London: Green Print.

Davidson, Richard J. (2003). Affective Neuroscience and Psychophysiology: Toward a Synthesis. Psychophysiology 40(5): 655-665.

Davis, James A., Tom W. Smith and Peter V. Marsden (2001). General Social Survey, 19722000: Cumulative Codebook. Storrs, CT: The Roper Center for Public Opinion Research.

Di Tella, Rafael and Robert MacCulloch (2005). Gross National Happiness as an Answer to the Easterlin Paradox? Mimeo, Harvard Business School.

Di Tella, Rafael and Robert MacCulloch (2006). Some Uses of Happiness Data in Economics. Journal of Economic Perspectives 20(1): 25-46.

Di Tella, Rafael, Robert J. MacCulloch and Andrew J. Oswald (2001). Preferences over Inflation and Unemployment: Evidence from Surveys of Happiness. American Economic Review 91(1): 335-341.

Diener, Ed (2005). Guidelines for National Indicators of Subjective Well-Being and Ill-Being. Mimeo, University of Illinois at Urbana Champaign.

Diener, Ed and Martin E.P. Seligman (2004). Beyond Money: Toward an Economy of WellBeing. Psychological Science in the Public Interest 5(1): 1-31.

Diener, Ed, Robert A. Emmons, Randy J. Larsen and Sharon Griffin (1985). The Satisfaction with Life Scale. Journal of Personality Assessment 49(1): 71-75.

Easterlin, Richard A. (1974). Does Economic Growth Improve the Human Lot? Some Empirical Evidence. In: Paul A. David and Melvin W. Reder (eds.). Nations and Households in Economic Growth: Essays in Honour of Moses Abramowitz. New York and London: Academic Press: 89-125.

Easterlin, Richard A. (1995). Will Raising the Incomes of All Increase the Happiness of All? Journal of Economic Behavior and Organization 27(1): 35-48.

Easterlin, Richard A. (2001). Income and Happiness: Towards a Unified Theory. Economic Journal 111(473): 465-484.

Edgeworth, Francis Y. (1881). Mathematical Psychics: An Essay on the Application of Mathematics to the Moral Sciences. London, UK: Kegan Paul.

Ehrhardt, Joop J., Willem E. Saris and Ruut Veenhoven (2000). Stability of Life-Satisfaction over Time: Analysis of Change in Ranks in a National Population. Journal of Happiness Studies 1(2): 177-205.

Estes, Richard (1988). Trends in World Social Development: The Social Progress of Nations, 1970-1987. New York: Praeger.

Fehr, Ernst, Urs Fischbacher and Michael Kosfeld (2005). Neuroeconomic Foundations of Trust and Social Preferences: Initial Evidence. American Economic Review 95(2): 346351.

Fernández-Dols, José-Miguel and María-Angeles Ruiz-Belda (1995). Are Smiles a Sign of Happiness? Gold Medal Winners at the Olympic Games. Journal of Personality and Social Psychology 69(6): 1113-1119. 
Forte, Francesco (2001). The Maastricht "Excessive Deficit" Rules and Creative Accounting. In: Ram Mudambi, Pietro Navarra and Giuseppe Sobbrio (eds.). Rules and Reason. Cambridge, UK: Cambridge University Press.

Frederick, Shane and George Loewenstein (1999). Hedonic Adaptation. In: Daniel Kahneman, Ed Diener and Norbert Schwarz (eds.). Well-Being: The Foundation of Hedonic Psychology. New York: Russell Sage Foundation: 302-329.

Frey, Bruno S. (1983). Democratic Economic Policy: A Theoretical Introduction. Oxford: Robertson.

Frey, Bruno S. (2008). Happiness: A Revolution in Economics. Cambridge, MA: MIT Press.

Frey, Bruno S. and Alois Stutzer (2000). Happiness, Economy and Institutions. Economic Journal 110(466): 918-938.

Frey, Bruno S. and Alois Stutzer (2002a). Happiness and Economics: How the Economy and Institutions Affect Well-Being. Princeton and Oxford: Princeton University Press.

Frey, Bruno S. and Alois Stutzer (2002b). What Can Economists Learn from Happiness Research? Journal of Economic Literature 40(2): 402-35.

Frey, Bruno S. and Alois Stutzer (2008). Economic Consequences of Mispredicting Utility. WWZ Discussion Paper No. 01/08, University of Basel.

Frey, Bruno S., Simon Luechinger and Alois Stutzer (2004). Valuing Public Goods: The Life Satisfaction Approach. IEW Working Paper No. 184, University of Zurich.

Gasper, Des (2005). Subjective and Objective Well-Being in Relation to Economic Inputs: Puzzles and Responses. Review of Social Economy 63(2): 177-206.

Goodhart, Charles A. E. (1975). Money, Information and Uncertainty. London: Macmillan.

Gruber, Jonathan H. and Sendhil Mullainathan (2005). Do Cigarette Taxes Make Smokers Happier. Advances in Economic Analysis and Policy 5(1): 1-43.

Hammond, Peter J. (1991). Interpersonal Comparisons of Utility: Why and How They Are and Should Be Made. In: Jon Elster and John E. Roemer (eds). Interpersonal Comparisons of Well-Being. Cambridge: Cambridge University Press: 200-254.

Hass, Julie L., Frode Brunvoll and Henning Hoie (2003). Overview of Sustainable Development Indicators Used by National and International Agencies. In: OECD (ed.). Documents De L'ocde, vol. 3(5). Paris: OECD: I-228

Helliwell, John F. (2007). Well-Being and Social Capital: Does Suicide Pose a Puzzle? Social Indicators Research 81(3): 455-496.

Hicks, John R. and Roy G. D. Allen (1934). A Reconsideration of the Theory of Value, I. Economica 1: 52-75.

Inglehart, Ronald, et al. (2000). World Values Surveys and Surveys and European Values Surveys, 1981-1984, 1990-1993, and 1995-1997 [Computer file]. ICPSR version. Ann Arbor, MI: Institute for Social Research [producer], 1999. Ann Arbor, MI: Interuniversity Consortium for Political and Social Research [distributor].

Jameson, Michael (1988). Practical Guide to Creative Accounting. London: Kogan Page.

Johns, Helen and Paul Ormerod (2007). Happiness, Economics and Public Policy. London: Institute of Economic Affairs.

Kahneman, Daniel and Alan B. Krueger (2006). Developments in the Measurement of Subjective Well-Being. Journal of Economic Perspectives 20(1): 3-24. 
Kahneman, Daniel and Richard H. Thaler (2006). Anomalies: Utility Maximization and Experienced Utility. Journal of Economic Perspectives 20(1): 221-234.

Kahneman, Daniel, Alan B. Krueger, David A. Schkade, Norbert Schwarz and Arthur A. Stone (2004a). A Survey Method for Characterizing Daily Life Experience: The Day Reconstruction Method. Science 306(5702): 1776-1780.

Kahneman, Daniel, Alan B. Krueger, David A. Schkade, Norbert Schwarz and Arthur A. Stone (2004b). Toward National Well-Being Accounts. American Economic Review 94(2): 429-34.

Kahneman, Daniel, Ed Diener and Norbert Schwarz (eds) (1999). Well-Being: The Foundations of Hedonic Psychology. New York, NY: Russell Sage Foundation.

Kahneman, Daniel, Peter P. Wakker and Rakesh Sarin (1997). Back to Bentham? Explorations of Experienced Utility. Quarterly Journal of Economics 112(2): 375-405.

Koivumaa Honkanen, Heli, Risto Honkanen, Heimo Viinamaki, Kauko Heikkila, Jaakko Kaprio and Markku Koskenvuo (2001). Life Satisfaction and Suicide: A 20-Year Follow-up Study. American Journal of Psychiatry 158(3): 433-439.

Lalive, Rafael and Alois Stutzer (2007). Approval of Equal Rights and Gender Differences in Well-Being. WWZ Discussion Paper No. 0607, University of Basel.

Layard, Richard (2005). Happiness: Lessons from a New Science. New York: Penguin.

Leigh, Andrew and Justin Wolfers (2006). Happiness and the Human Development Index: Australia Is Not a Paradox. Australian Economic Review 39(2): 176-184.

Lepper, Heidi S. (1998). Use of Other-Reports to Validate Subjective Well-Being Measures. Social Indicators Research 44(3): 367-379.

Michalos, Alex C. (ed.) (2005). Citation Classics from Social Indicators Research. The Most Cited Articles. Dordrecht: Springer.

Mueller, Dennis C. (1996). Constitutional Democracy. New York: Oxford University Press.

Mueller, Dennis C. (2003). Public Choice III. Cambridge, New York and Melbourne: Cambridge University Press.

Nordhaus, William and James Tobin (1972). Is Growth Obsolete? Nber General Series No. 96. New York: Columbia University Press.

Nussbaum, Martha C. (1999). Sex and Social Justice. Oxford: Oxford University Press.

Nussbaum, Martha C. (2000). Women and Human Development : The Capabilities Approach. Cambridge: Cambridge University Press.

Oreopoulos, Philip (2005). Do Dropouts Drop out Too Soon? Wealth, Health, and Happiness from Compulsory Schooling. Mimeo, Department of Economics, University of Toronto.

Oswald, Andrew J. and Nattavudh Powdthavee (2008). Does Happiness Adapt? A Longitudinal Study of Disability with Implications for Economists and Judges. Journal of Public Economics 92(5-6): 1061-1077.

Pezzini, Silvia (2005). The Effect of Women's Rights on Women's Welfare: Evidence from a Natural Experiment. Economic Journal 115(502): C208-C227.

Pugno, Maurizio (2004). Rationality and Affective Motivations: New Ideas from Neurobiology and Psychiatry for Economic Theory? Discussion Paper No. 1, Deparetment of Economics, University of Trento.

Rabin, Matthew (1998). Psychology and Economics. Journal of Economic Literature 36(1): 11-46. 
Robbins, Lionel C. (1932). An Essay on the Nature and Significance of Economic Science. London: Macmillan. Selections reprinted in Daniel M. Hausman (Ed.). (1984) The Philosophy of Economics: An Anthology. New York: Cambridge University Press.

Robinson, Michael D. and Gerald L. Clore (2002). Belief and Feeling: Evidence for an Accessibility Model of Emotional Self-Report. Psychological Bulletin 128(6): 934-960.

Sandvik, Ed, Ed Diener and Larry Seidlitz (1993). Subjective Well-Being: The Convergence and Stability of Self-Report and Non-Self-Report Measures. Journal of Personality 61(3): 317-342.

Schimmack, Ulrich and Shigehiro Oishi (2005). The Influence of Chronically and Temporarily Accessible Information on Life Satisfaction Judgments. Journal of Personality and Social Psychology 89(3): 395-406.

Schwarz, Norbert and Fritz Strack (1999). Reports of Subjective Well-Being: Judgmental Processes and Their Methodological Implications. In: Daniel Kahneman, Ed Diener and Norbert Schwarz (eds.). Well-Being: The Foundations of Hedonic Psychology. New York: Russell Sage Foundation: 61-84.

Scollon, Christie Napa, Chu Kim Prieto and Ed Diener (2003). Experience Sampling: Promises and Pitfalls, Strengths and Weaknesses. Journal of Happiness Studies 4(1): 534.

Sen, Amartya K. (1970). Collective Choice and Social Welfare. San Francisco: Holden-Day.

Sen, Amartya K. (1985). Commodities and Capabilities. Amsterdam: North Holland.

Sen, Amartya K. (1992). Inequality Reexamined. New York: Russel Sage.

Sen, Amartya K. (1995). Rationality and Social Choice. American Economic Review 85(1): 124.

Sen, Amartya K. (1999). Development as Freedom. New York: Alfred Knopf.

Shah, Hetan and Nic Marks (2004). A Well-Being Manifesto for a Flourishing Society. London: New Economics Foundation.

Slesnick, Daniel T. (1998). Empirical Approaches to the Measurement of Welfare. Journal of Economic Literature 36(4): 2108-2165.

Stutzer, Alois (2004). The Role of Income Aspirations in Individual Happiness. Journal of Economic Behavior and Organization 54(1): 89-109.

Stutzer, Alois and Bruno S. Frey (2006). Does Marriage Make People Happy, or Do Happy People Get Married? Journal of Socio-Economics 35(2): 326-347.

Stutzer, Alois and Bruno S. Frey (2007). What Happiness Research Can Tell Us About SelfControl Problems and Utility Misprediction. In: Bruno S. Frey and Alois Stutzer (eds.). Economics and Psychology. A Promising New Cross-Disciplinary Field. Cambridge: MIT Press.

Theil, Henri (1964). Optimal Decision Rules for Government and Industry. Amsterdam: North Holland.

Tinbergen, Jan (1956). Economic Policy: Principles and Design. Amsterdam: North Holland.

United Nations Development Programme (2005). Human Development Report 2005. New York: United Nations Development Programme.

Ura, Karma and Karma Galay (eds.) (2004). Gross National Happiness and Development. Thimpu: The Centre for Bhutan Studies. 
Urry, Heather L., J. B. Nitschke, I. Dolski, D. C. Jackson, K. M. Dalton, C. J. Mueller, M. A. Rosenkranz, C. D. Ryff, B. H. Singer and R. J. Davidson (2004). Making a Life Worth Living - Neural Correlates of Well-Being. Psychological Science 15(6): 367-372.

van Praag, Bernard M.S. and Ada Ferrer-i-Carbonell (2004). Happiness Quantified - A Satisfaction Calculus Approach. Oxford: Oxford University Press.

Vanberg, Viktor J. (2005). Market and State: The Perspective of Constitutional Political Economy. Journal of Institutional Economics 1(1): 23-49.

von Hagen, Jürgen and Guntram B. Wolff (2004). What Do Deficits Tell Us About Debts?: Empirical Evidence on Creative Accounting with Fiscal Rules in the EU. Series 1: Studies of the Economic Research Centre. Discussion Paper No. 38, Deutsche Bundesbank.

Wilkinson, Will (2007). In Pursuit of Happiness Research: Is It Reliable? What Does It Imply for Policy? Policy Analysis No. 590, Washington D.C.

Zak, Paul J. (2004). Neuroeconomics. Philosophical Transactions of the Royal Society of London Series B-Biological Sciences 359(1451): 1737-1748.

Zolatas, Xenophon (1981). Economic Growth and Declining Social Welfare. Athens: Bank of Greece. 